\title{
An Overview of Medicinal Plants as Potential Anti-Platelet Agents
}

\author{
Mridul Bhowal ${ }^{1}$, Darshika M Mehta ${ }^{2}$ \\ ${ }^{1} B$ Pharm, PES College of Pharmacy, 50 feet road, Hanumanthanagar, Bengaluru-560050, Karnataka, India \\ ${ }^{2}$ UG Scholar, PES College of Pharmacy, 50 feet road, Hanumanthanagar, Bengaluru-560050, Karnataka, India
}

\begin{abstract}
Anti-platelet agents are those that decrease platelet aggregation and inhibit thrombus formation. Anti-platelet drugs are used to prevent and help in the reversal of platelet aggregation in arterial thrombosis which is the principal reason in the pathology of myocardial infarction (MI) and ischemic stroke. Currently many synthetic and semi-synthetic formulations are available in the markets which are potent anti-platelet agents but they have significant adverse effects. Herbs have been always an ideal source of drugs and numerous of the presently available drugs have been obtained directly or indirectly from them. In this article, authors made an extensive literature study about the work carried out on herbs with anti-platelet activity and their bioactive constituent. Here, an attempt was made to elaborate the isolated constituents from plant origin, which showed promising activity as anti-platelet agent.
\end{abstract}

Keywords: Anti-platelet, Constituents, Extracts, Herbs, Medicinal Plants

\section{Introduction}

Platelets play an essential role in the initial response to vascular injury [1]. Its activation leads to formation of a haemostatic plug at the site of injury. Activation of platelets is therefore crucial for normal haemostasis but, uncontrolled platelet activation may also lead to the formation of occlusive thrombi that can cause ischemic events [2] and thus, anti-platelet therapy is very much needed for treatment. Numerous studies have recorded the anti-platelet activities of natural products over last four lustrum [3].

For the past 2500 years, the traditional system of medicines such as Chinese, Ayurveda and Unani have been very strong. These traditions are still prospering. Roughly $80 \%$ of the people in the developing countries depend on these systems of medicine for their primary health care needs $[4,5]$. The World Health Organisation (WHO) accounts that from 119 plant-derived pharmaceutical medicines; about $74 \%$ are used in modern medicine in ways that corresponds directly with their traditional uses as plant medicines by native cultures. Major pharmaceutical companies are currently conducting extensive research on plant materials gathered from the rain forests and other places for their potential medicinal value. About 25 percent of today's prescription drugs are at least partially derived from plants $[6,7]$.

This paper present a review focused on experimental studies performed on herbs with anti-platelet activity and their bioactive constituent. Comprehensive literature review was carried out using Google Scholar, PubMed, Chemical abstracts, as well as the journals. We believe the list of medicinal plants represented in this article will be beneficial to researchers and practioners.

TABLE 1: Anti-Platelet Constituents from Medicinal Plants.

\begin{tabular}{|l|l|l|l|}
\hline \multicolumn{1}{|c|}{ Plant Name } & Plant Part/Extraction & \multicolumn{1}{c|}{ Bioactive Compound } \\
\hline Allium sativum & Garlic oil & $\begin{array}{l}\text { Diallyl disulphide and } \\
\text { Diallyl trisulphide }\end{array}$ & {$[8]$} \\
\hline Allium cepa & Bulb & Adenosine; Allicin; Paraffinic Polysulfides & [9] \\
\hline Areca catechu & Aqueous-Methanolic & Catechin & {$[10]$} \\
\hline Artocarpus communis & Roots & $\begin{array}{l}\text { Dihydroartomunoxanthone; Artochamins B; } \\
\text { Artocommunol CC }\end{array}$ & [11] \\
\hline Annona purpurea & $\begin{array}{l}\text { Methanolic extract of } \\
\text { leaves }\end{array}$ & $\begin{array}{l}\text { Oxopurpureine; Oxonuciferine; Oxoglaucine; } \\
\text { (+)-Predicentrine; Thalbaicalidine; } \\
\text { Thalicpureine; Dehydrolirinidine; } \\
\text { 7-hydroxy-dehydroglaucine }\end{array}$ & [12] \\
\hline Andrographis paniculata & Leaves & Andrographolide \\
\hline Achillea santolina & $\begin{array}{l}\text { Diethylether fraction of } \\
\text { the Crude extract of } \\
\text { leaves }\end{array}$ & $\begin{array}{l}\text { Flavonoids and } \\
\text { Sesquiterpene lactone }\end{array}$ & {$[13]$} \\
\hline Artemisia dracunculus & Essential oil & Phenylpropanoids \\
\hline Cassytha filiformis & $\begin{array}{l}\text { Methanolic extract of } \\
\text { the fresh herbs }\end{array}$ & $\begin{array}{l}\text { Cathafiline; } \\
\text { Cathaformine; Actinodaphnine; } \\
\text { N-methylactinodaphnine; Predicentrine; } \\
\text { Ocoteine }\end{array}$ \\
\hline
\end{tabular}


An Overview of Medicinal Plants as Potential Anti-Platelet Agents

\begin{tabular}{|c|c|c|c|}
\hline Curcuma wenyujin & Essential oil & Curdione & [17] \\
\hline Cudrania tricuspidata & Roots & Cudratricusxanthone A & {$[18]$} \\
\hline Curcuma longa & Rhizome & Ar-tumerone & [19] \\
\hline Coleus forskohlii & Roots & Forskolin & {$[20]$} \\
\hline Corydalis tashiroi & Entire Plant & $\begin{array}{l}\text { Tetrahydroprotoberberine } \\
\text { N-oxide alkaloid; } \\
\text { (-)-cis-isocorypalmine N-oxide; } \\
\text { 6-methoxydihydrosanguinarine; } \\
\text { Norjuziphine; } \\
\text { (-)-cis-corydalmine N-oxide; } \\
\text { (-)-trans-corydalmine N-oxide; } \\
\text { (-)-trans-isocorypalmine N-oxide; } \\
\text { Scoulerine; } \\
\text { Protopine; Oxysanguinarine; Corydalmine }\end{array}$ & {$[21]$} \\
\hline Elephantopus scaber & Leaves & Lupeol & {$[22]$} \\
\hline Foeniculum vulgare & Essential oil & Anethole & {$[23,24]$} \\
\hline Filipendula ulmaria & Flowers & Heparin & {$[25,26]$} \\
\hline Ginkgo biloba & Petroleum ether extract & Isoginkgetin & [27] \\
\hline Gynura japonica & Rhizome & $\begin{array}{l}\text { Caryophyllene oxide; 6-acetyl-2, 2-dimethylchroman-4- } \\
\text { one; Vanillin; 2, 6- dimethoxy- 1, 4- benzoquinone; } \\
\text { benzoic acid }\end{array}$ & [28] \\
\hline Glycyrrhiza glabra & $\begin{array}{l}\text { Aqueous extracts of } \\
\text { roots }\end{array}$ & $\begin{array}{l}\text { 3-(3,4-dihydroxyphenyl)-8-hydroxymethyl-8-methyl-5- } \\
\text { methoxy-6,7-dihydro-2H,8H-benzo(1,2-b;5,4-b')dipyran- } \\
\text { 2-one }\end{array}$ & [29] \\
\hline Hernandia Sonora & Stem bark & $\begin{array}{l}\text { Ovigerine; Hernangerine; N-methylhernangerine, (+)- } \\
\text { malekulatine; Isovanillin }\end{array}$ & [30] \\
\hline Hypericum geminiflorum & $\begin{array}{l}\text { Heartwood, Leaves, } \\
\text { Roots }\end{array}$ & Gemichalcone A & {$[31]$} \\
\hline Justicia procumbens & Ethanolic extract & $\begin{array}{l}\text { Neojusticin A; Justicidin B; } \\
\text { Taiwanin E methyl ether; } \\
\text { Taiwanin E }\end{array}$ & {$[32]$} \\
\hline Leuzea carthamoides & Ethanolic extract & $\begin{array}{l}\text { Eriodictyol; Patuletin; Eriodictyol-7- } \beta \text {-glucopyranoside; 6- } \\
\text { hydroxykaempferol-7- } O \text { - }(6 "-O \text {-acetyl- } \beta \text {-D [small cap]- } \\
\text { glucopyranoside) }\end{array}$ & [33] \\
\hline Leonurus japonicus & Aerial parts & (13R)-bis-spirolabdane diterpenoids & [34] \\
\hline Lindera obtusiloba & Ethanolic extract & Polyphenols & [35] \\
\hline Lonicera japonica & Flowers & Protocatechuic acid & [36] \\
\hline Magnolia obovata & $\begin{array}{l}\text { Methanolic extract of } \\
\text { barks and fruits }\end{array}$ & Magnolol; Honokiol; Obovatol; Syringin; Methyl caffate & [37] \\
\hline $\begin{array}{l}\text { Melicope } \\
\text { semecarpifolia }\end{array}$ & Root bark & Quinoline Alkaloids & [38] \\
\hline Ocotea quixos & Essential oil & Phenylpropanoids & [39] \\
\hline Operculina macrocarpa & Roots & Chlorogenic; Caffeic acids; Gallic acids & [40] \\
\hline Piper longum & Fruits & Piperlonguminine & [41] \\
\hline Petroselinum crispum & Leaves & Genins & [42] \\
\hline Peucedanum japonicum & Roots & $\begin{array}{l}\text { Eugenin; (-)-selinidin; (+)-pteryxin, Imperatorin; } \\
\text { Bergapten; Cnidilin; (+)-visamminol }\end{array}$ & [43] \\
\hline Persea Americana & Fruit pulp & $\begin{array}{l}\text { Persenone-C and } \\
\text { Persenone A }\end{array}$ & [44] \\
\hline Perganum harmala & Decoction of seeds & $\beta$-carboline alkaloids & {$[45,46]$} \\
\hline Pogostemon cablin & Water extract & $\alpha$-Bulnesene & [47] \\
\hline Rhus verniciflua & Heart wood extract & Fisetin; Butein; Sulfuretin & {$[48]$} \\
\hline Rhamnus nakaharai & Stem bark & $\begin{array}{l}\text { Isotorachrysone; } \\
\text { Isotorachrysone peracetate; } \\
\text { Quercetin 3-O-methyl ether; } \\
\text { Quercetin 3-O-methyl ether peracetate }\end{array}$ & [49] \\
\hline Salvia milthorriza & Roots & Tanshinone II & {$[50]$} \\
\hline Varthemia iphionoides & $\begin{array}{l}\text { Decoction of shoots, } \\
\text { leaves }\end{array}$ & Boiss and Blanche & $\begin{array}{l}{[51,52,} \\
53]\end{array}$ \\
\hline Yucca schidigera & Bark & $\begin{array}{l}\text { Resveratrol; trans-3,3',5,5'-tetrahydroxy-4'- } \\
\text { methoxystilbene; Yuccaols }\end{array}$ & {$[54]$} \\
\hline Zanthoxylum schinifolium & $\begin{array}{l}\text { Chloroform-soluble } \\
\text { portion of the root bark }\end{array}$ & Terpenyl-coumarins and Furoquinolines & {$[55]$} \\
\hline Zanthoxylum simulans & Root bark & Huajiaosimuline & {$[56]$} \\
\hline Zingiber officinale & Rhizomes & (6)-gingerol \& (6)-Shogaol & [57] \\
\hline Zizyphus jujuba & $\begin{array}{l}\text { Ethanolic extract } \\
\text { of Seeds }\end{array}$ & Jujuboside A and Jujuboside B & [58] \\
\hline
\end{tabular}




\section{Conclusion}

Comprehensive details of medicinal plants with anti-platelet activity have been presented in this review. The herbs mentioned in this extensive study are those which possess anti-platelet activity. There are many synthetic formulations available in market, though they are showing magnificent clinical and pharmacological activity as an anti-platelet agent but they have significantly notable adverse effect. Hence, herbal drugs are favoured over synthetic formulations in order to avoid serious adverse and side effects; however one has to be very careful about the use of medicinal plants due to the fact that quality control regulations are too pliable in India. Department of AYUSH and other Government governing bodies have to encourage the herbal drug manufacturers to set up the quality control parameters.

So far, very few studies have been carried out on medicinal plants which present anti-platelet potency, further investigations are need to be carried out to evaluate the mechanism of actions of medicinal plants with anti-platelet effect and increase the isolation of the newer molecules having anti-platelet potential.

\section{References}

[1]. N Wohner, Role of Cellular Elements in Thrombus Formation and Dissolution, Cardiovasc Hematol Agents Med Chem, 6(3), 2008; 224-28.

[2]. M Schattner, Platelets and galectins, Annals of Translational Medicine, 2(9), 2014, 85

[3]. KC Srivastava, and T Mustafa, Spices: Antiplatelet activity and prostanoid metabolism, Leukotr Essent Fatty Acids, 38(4), 1989, 255-266.

[4]. ANM Mamun-or-Rashid, Md. Shamim Hossain, Naim Hassan, Biplab Kumar Dash, Md. Ashrafuzzaman Sapon, and Monokesh Kumer Sen, A review on medicinal plants with antidiabetic activity, Journal of Pharmacognosy and Phytochemistry, 3(4), 2014, 149-59.

[5]. Tsay HS, and Agrawal DC, Tissue Culture Technology of Chinese Medicinal Plant Resources in Taiwan and their Sustainable Utilization, International Journal of Applied Science and Engineering, 3(3), 2005, 215-23.

[6]. Murugananthan G, Sudheer KG, Sathya CP, and Mohan S, Anti-Arthritic and Anti-Inflammatory Constituents from Medicinal Plants, Journal of Applied Pharm Sciences, 3(04), 2013, 161-64.

[7]. Hegen M, Keith JC, and Collins M, Utility of Animal models for identification of potential therapeutics for rheumatoid arthritis, Ann Rheum Dis, 67(11), 2008, 1505-15.

[8]. Bordia A, Verma SK, and Srivastava KC, Effect of garlic (Allium sativum) on blood sugar, fibrinogen and fibrinolytic activity in patients with coronary artery disease, Prostaglandins Leukot Essent Fatty Acids, 58(4), 1998, 257-63.

[9]. Makheja AN, and Bailey JM, Antiplatelet constituents from garlic and onion, Agents and Actions, 29(3-4), $1990,360-63$.

[10]. Ghayur MN, Kazim SF, Rasheed H, Khalid A, Jumani MI, Choudhary MI, and Gilani AH, Identification of antiplatelet and acetylcholinesterase inhibitory constituent in betel nut, Zhong Xi Yi Jie He Xue Bao, 9(6), 2011, 619-25.

[11]. Weng JR, Chan SC, Lu YH, Lin HC, Ko HH, and Lin CN, Antiplatelet prenylflavonoids from Artocarpus communis. Phytochemistry, 67(8), 2006, 824-29.

[12]. Chang FR, Wei JL, Teng CM, and Wu YC, Antiplatelet aggregation constituents from Annona purpurea, J Nat Prod, 61(12), 1998, 1457-61.

[13]. Lien LM, Su CC, Hsu WH, Lu WJ, Chung CL, Yen TL, Chiu HC, Sheu JR, and Lin KH, Mechanism of Andrographolide-induced platelet apoptosis in human platelets: regulatory roles of the extrinsic apoptotic pathway, Phytother Res, 27(11), 2013, 1671-77.

[14]. Najim AJAA, Effects of Achillea Santolina extracts and fractions on human platelet aggregation in vitro and on rat arteriovenous shunt thrombosis in vivo, Thi-Qar Med J, 4(3), 2010, 131-41.

[15]. Tognolini M, Barocelli E, Ballabeni V, Bruni R, Bianchi A, Chiavarini M, and Impicciatore M, Comapritive screening of plant essential oils: Phenylpropanoid moiety as basic core for antiplatelet activity, Life Sciences, 78 (13), 2006, $1419-32$.

[16]. Chang FR, Chao YC, Teng CM, and Wu YC, Chemical Constituents from Cassytha filiformis II, J Nat Prod, 61(7), 1998, 863-66.

[17]. Xia Q, Wang X, Xu DJ, Chen XH, and Chen FH, Inhibition of platelet aggregation by curdione from Curcuma wenyujin essential oil, Thromb Res, 130(3), 2012, 409-14.

[18]. Sim J, Choi E, Lee YM, Jeong GS, and Lee S, In vitro inhibition of human cytochrome P450 by cudratricusxanthone A, Food Chem Toxicol, 81, 2015, 171-5.

[19]. Lee HS, Antiplatelet property of Curcuma Longa L. rhizome- derived ar-tumerone, Bioresource Tech, 97(12), 2006, 1372-76.

[20]. Agarwal KC, Zielinski BA, and Maitra RS, Significance of plasma adenosine in the antiplatelet activity of forskolin: potentiation by dipyridamole and dilazep, Thromb Haemost, 61(1), 1989, 106-10.

[21]. Chen JJ, Chang YL, Teng CM, Linn WY, Chen YC, and Chen IS, A new tetrahydroprotoberberine N-oxide alkaloid and antiplatelet aggregation constituents of Corydalis tashiroi, Planta Medica, 67(5), 2001, 423-7.

[22]. Sankarnarayanan S, Bama P, Ramachandran J, Jayasimman R, Kalaichelvan PT, Deccaraman M, Vijayalakshimi M, Visveswaran $\mathrm{M}$, and Chitibabu CV, In vitro platelet aggregation inhibitory effect of triterpenoid compound from the leaf of Elephantopus scaber Linn, Int J Pharmacy and Pharmaceutical Sci, 2(2), 2010, 49-51.

[23]. Tognolini M, Ballabeni V, Bertoni S, Bruni R, Impicciatore M, and Barocelli E, Protective effect of Foeniculum Vulgare essential oil and anethole in an experimental model of thrombosis, Pharmacol Res, 56(3), 2007, 254-60.

[24]. Manzoor AR, Bilal AD, Shahnawaz NS, Bilal AB, and Mushtaq AQ, Foeniculum Vulgare: A comprehensive review of its traditional use, phytochemistry, pharmacology, and safety, Arabian Journal of Chemistry, 9(2), 2016, 1574-83

[25]. Kudriashov BA, Liapina LA, and Azieva LA, [The content of heparin-like anticoagulant in the flowers of meadowseweet (Filipendula ulmaria)], Farmakologiia i Toksikologiia, 53(4), 1990, 39-41.

[26]. Kudriashov BA, Ammosoval IaM, Liapina LA, Osipova NN, Azieva LD, Liapin Glu, and Basanova AV, [Heparin from the meadowsweet (Filipendula ulmaria) and its properties], Izv Akad Nauk SSSR Biol, 6, 1991, 939-43.

[27]. Zhou G, Yao X, Tang Y, Yang N, Pang H, Mo X, Zhu S, Su S, Qian D, Jin C, Qin Y, and Duan JA, Two new nonacosaneteriols from Ginkgo biloba sarcotesta, Chemistry and Physics of Lipids, 165 (7), 2012, 731-36.

[28]. Lin WY, Kuo YH, Chang YL, Teng CM, Wang EC, Ishikawa T, and Cheng IS, Anti-platelet aggregation and chemical constituents from the rhizome of Gynura japonica, Planta Medica, 69 (8), 2003, 757-64.

[29]. Masato Tawata, Yoshiki Yoda, Kaoru Aida, Hideo Shindo, Hiroshi Sasaki, Masao Chin, and Toshimasa Onaya, Anti-Platelet Action of GU-7, A 3-Arylcoumarin Derivative, Purified from Glycyrrhizae Radix, Planta Med, 56(3), 1990, $259-263$. 
[30]. Chen IS, Chen JJ, Tsai IL, Chang YL, and Teng CM, New p-quinonoid aporphine alkaloids and antiplatelet aggregation constituents of Hernandia Sonora, Planta Med, 61(6), 1995, 537-9.

[31]. Chung MI, Weng JR, Wang JP, Teng CM, and Lin CN, Anti-platelet and anti-inflammatory constituents and new oxygenated xanthones from Hypericum geminiflorum, Planta Med, 68(1), 2002, 25-29.

[32]. ] Chen CC, Hsin WC, Ko FN, Huang YL, Ou JC, and Teng CM, Antiplatelet arylnapthalide lignans from justice procumbens, J Nat Prod, 59(12), 1996, 1149-50.

[33]. Koleckar V, Brojerova E, Rehakova Z, Kubikova K, Cervenka F, Kuca K, Jun D, Hronek M, Opletalova V, and Opletal L, In Vitro Antiplatelet Activity of Flavonoids from Leuzea Carthamoides, Drug and Chemical Toxicology, 31(1), 2008, 27-35.

[34]. Liang Xiong, Qin-Mei Zhou, Cheng Peng, Xiao-Fang Xie, Lu-Si Liu, Li Guo, et al, Bis-spirolabdane diterpenoids from Leonurus japonicas and their anti-platelet aggrergative activity, Fitoterapia, 100, 2015, 1-6.

[35]. Lee JO, Kim C, Lee SW, and Oak MH, Antiplatelet and antithrombotic activities of Lindera obtusiloba extract in vitro and in vivo, Biomolecules \& Therapeutics, 18(2), 2010, 205-10.

[36]. Kim K, Bae ON, Lim KM, Noh JY, Kang S, Chung KY, and Chung JH, Novel antiplatelet activity of Procatechuic acid through the inhibition of high shear stress-induced platelet aggregation, The Journal of Pharmacology and Experimental Therapeutics, 343(3), 2012, 704-11.

[37]. Mi Kyung Pyo, Young Yook Lee, and Hye SOok Yun-Choi, Anti-platelet effect of the constituents isolated from the barks and fruits of Magnolia obovate, Pharmacal Research, 25, 2002, 325-28.

[38]. Chen IS, Chen HF, Cheng MJ, Chang YL, Teng CM, Tsutomu I, Chen JJ, and Tsai IL, Quinoline Alkaloids and Other Constituents of Melicope semecarpifolia with Antiplatelet Aggregation Activity, J Nat Prod, 64(9), 2001, 1143-47.

[39]. Tognolini M, Barocelli E, Ballabeni V, Bruni R, Bianchi A, Chiavarini M, and Impicciatore M, Comapritive screening of plant essential oils: Phenylpropanoid moiety as basic core for antiplatelet activity, Life Sciences, 78(13), 2006, $1419-32$.

[40]. Taiana MP, Nathalia RL, Raony CMR, Jonas PT, Romélia PG, Juvenia BF, Silvânia MMV, Glauce Socorro BV, and Luzia KAML, The Operculina macrocarpa (1.) urb. (jalapa) tincture modulates human blood platelet aggregations, Journal of Ethnopharmacology, 151(1), 2014, 151-57.

[41]. Lee W, Yoo H, Ku SK, Kim JA, and Bae JS, Anticoagulant activities of Piperlonguminine invitro and invivo, BMB reports, 46(10), 2013, 484-89.

[42]. Gadi D, Bnouham M, Aziz M, Ziyyat A, Legssyer A, Bruel A, Berrabah M, Legrand C, Fauvel-Lafeve F, and Mekhfi H, Flavonoids Purified from parsley inhibit human blood platelet aggregation and adhesion to collagen under flow, Journal of Complementary and Integrative Medicine, 9, 2012, Article 19.

[43]. Chen IS, Chang CT, Sheen WS, Teng CM, Tsai IL, Duh CY, and Ko FN, Coumarins and antiplatelet aggregation constituents from Formosan Peucedanum japonicum, Phytochemistry, 41(2), 1996, 525-30.

[44]. Rodriguez-Sanchez DG, Flores-Garcia M, Silva-Platas C, Rizzo S, Torre-Amione G, De la Pena-Diaz A, et al, Isolation and chemical identification of lipid derivatives from avocado (Persea Americana) pulp with antiplatelet and antithrombotic activities, Food \& Function, 6(1), 2015, 193-203.

[45]. Im JH, Jin YR, Lee JJ, Yu JY, Han XH, Im SH, Hong JT, Yoo HS, Pyo MY, and Yun YP, Antiplatelet activity of beta-carboline alkaloids from Perganum harmala: a possible mechanism through inhibiting PLCgamma2 phosphorylation, Vascul Pharmacol, 50(5-6), 2009, 147-152.

[46]. Lev E, and Amar Z, Ethnopharmacological survey of traditional drugs sold in Israel at the end of the 20th century, $J$ Ethnopharmacol, 72(1-2), 2000, 191-205.

[47]. Hui-Chun Hsu, Wen-Chia Yang, Wei-Jern Tsai, Chien-Chih Chen, Hui-Yu Huang, and Ying-Chieh Tsai, $\alpha$ - Bulnesene, a novel PAF receptor antagonist isolated from Pogostemon cablin, Biochemical and Biophysical Research Communications, 345 (3), 2006, 1033-38.

[48]. Lee JH, Kim M, Chang KH, Hong CY, Na CS, Dong MS, Lee D, and Lee MY, Antiplatelet effects of Rhus verniciflua stokes heartwood and its active constituents-- fistein, butein, and sulfuretin-- in rats, Journal of Medicinal Food, 18(1), 2015, 21-30.

[49]. Lin CN, Lu CM, Lin HC, Ko Fn, and Teng CM, Novel antiplatelet naphthalene from Rhamnus nakaharai, Journal of Natural Products, 58(12), 1995, 1934-50.

[50]. Maione F, De Feo, Caiazzo E, De Martino L, Cicala C, and Mascolo N, Tanshinone IIA, a major component of Salvia milthorriza Bunge, inhibits platelet activation via Erk-2 signaling pathway, Journal of Ethnopharmacology, 155(2), $2014,1236-42$.

[51]. Abu Irmaileh B, and Afifi F, Treatment with medicinal plants in Jordan, Dirasat, 27, 2000, 53-74.

[52]. Hudaib M, Mohammad M, Bustanji Y, Tayyem R, Yousef M, Abuirjeie M, and Aburjai T, Ethnopharmacological survey of medicinal plants in Jordan, Mujib Nature Reserve and surrounding area, Journal of Ethnopharmacology, 120(1), $2008,63-71$.

[53]. Afifi F, and Aburjai T, Antiplatelet activity of Varthenmia iphionoides, Fitoterapia, 75(7-8), 2004, 629-633.

[54]. Wenzig EM, Oleszek W, Stochmal A, Kunert O, and Bauer R, Influence of phenolic constituents from Yucca schidigera bark on arachidonate metabolism in vitro, Journal of Agricultural and Food Chemistry, 56(19), 2008, 8885-90.

[55]. Tsai IL, Lin WY, Teng CM, Ishikawa T, Doong SL, Huang MW, Chen YC, and Chen IS, Coumarins and antiplatelet constituents from the root bark of Zanthoxylum schinifolium, Planta Medica, 66(7), 2000, 618-23.

[56]. Chen IS, Wu SJ, and Tsai IL, Chemical and bioactive constituents from Zanthoxylum simulans, Journal of Natural Products, 57(9), 1994, 1206-11

[57]. Yu-Ren Liao, Yann-Lii Leu, Yu-Yi Chan, Ping-Chung Kuo, and Tian-Shung Wu, Anti-platelet aggregation and vasorelaxuing effects of the constituents of the rhizomes of Zingiber officinale, Molecules, 17(8), 2012, 8928-37.

[58]. Seo EJ, Lee SY, Kang SS, and Jung YS, Zizyphus jujube and its active component jujuboside B inhibit platelet aggregation, Phytotherapy Research, 27(6), 2013, 829-34. 